and 5 parts of water, so that a bluish milk liquid is produced, which is mixed with the water glass solution. In place of the glue or blood, fresh curds may be used and dissolved in the water-glass solution, into which the aqueous mineral color solution is introduced. Berlin blue or Paris blue cannot be used because they would be decomposed by the alkaline constituents of the water glass. The paint should be applied thinly to the casks, which must be first rubbed off (scoured) with lime water, if possible in several coats, but never a second coat applied until the previous coat is dry.

\title{
PHOTOGRAPHY IN WORLD PROGRESS.
}

\author{
ITS VALUE TO SCIENCE.
}

\section{B Y W. I. S C A N D I I N.}

How MaNY people ever pause to consider the tre mendous importance of photography in everyday life? Few, I believe, and even these often fail of its full appreciation from inability to establish a proper viewpoint.

Suppose it were possible for the reader to forget, for the moment, every impression that photography has made upon his mind, and to compare its emptiness with his present knowledge. He might the form some conception of its importance to himself, form some conception of its importance to himself
but would still miss much of its scope in fields with but would still miss m
which he is unfamiliar.

which he is unfamiliar.
Born, as it was, only sixty-eight years ago with Daguerre's discovery of a method for making su pictures, photography has been developed, its methods improved, its scope extended, and its field of usefulness enlarged, until to-day it enters into every branch of scientific research, popular education, commercial activity, legal investigation, manufacturing achievement, military and naval warfare, pathological and surgical work, and into the exposition and consequen improvement of local conditions in every section of the civilized world.

Without photography or its equivalent, in its single application to the printing press for instance, the illustrations of the world to-day would be limited to the hand work of the artist, engraver, etcher, or lithographer of seventy years ago.

In its earliest stages, a single picture only wa possible from each photographic exposure; but so rapid was its development, that only a few years passed before negatives were produced from which duplicate impressions could be printed. These negatives were at first crude, made on writing paper sensitized, and rendered translucent by the applica tion of hot wax. The great length of exposure made portraiture a difficult achievement; but as early as 1853 Victor Provost, a talented French artist and student of photography, produced a remarkable serie of such waxed paper negatives, probably the first eve attempted for illustrative purposes. They include views in and about Castle Pierrefonds, France, made famous by the elder Dumas in his "Twenty Years After." Made within fourteen years of Daguerre's After." Made within fourteen years of Daguerre's discovery, these negatives form one of the most im-
portant exhibits of early photography in its application to the illustration of historic literature.

With the simplification of processes, improvement in media and apparatus, the practice of photography has long since become universal; the work of the amateur is everywhere in evidence, and many of the most important advances in its applied fields are due to his efforts. Traveling every portion of the globe, he has not only exchanged pictorial records of modern he has not only exchanged pictorial records of modern
civilization, but has also spread broadcast graphic illustrations of dynasties long dead. Thus photogra phy has brought to the student of archeology the ruins of Egypt, the caves of the cliff dwellers, the relics of the Norsemen, and even the crude symbols of prehistoric man scratched in stone and ivory.

Every landscape photograph is a study in physical geography, picturing with a vividness and reality impossible in any other way, the vast ice fields of the frozen North, the tangled jungles of the tropic zones, and every physical feature lying between. It show to the student in nature's own handwriting the course of mighty glaciers and of rivers long dried up; it tells the story of her cataclysms-of avalanche, earthquake, flood, volcano, and of tidal wave. It shows where the timber belt changes and at last stops short as the higher altitudes are reached; the mines and how the mineral wealth is dug from out the bowels of the mineral wealth is dug fiom out the bowels of the
earth and made to serve man's multitudinous require earth and made to serve man's multitudinous require-
ments; rolling grain fields of the agricultural section; the cattle ranges of the West; the pampas of Brazil the steppes of Russia. All these things and thousand more with which the world to-day is familiar, but which, without photography, would be, to the majority of mankind, a sealed book.

The student of natural history finds in it a means of obtaining accurate information upon many points impossible of solution prior to its introduction. Th world-renowned achievements of Mr. Edweard Muy-

* Former editor The International Annual of Photography, etc. bridge some thirtv years ago in photographing birds and animals in motion have been followed everywhere by similar contributions, which have revolutionized many existing theories, and have thrown much new light upon the haunts and habits of the fauna of the world.

In the picturing of plant life, vegetable and fruit formation, the growth of fungi, insect life, the delicate tracery of the spider's architecture, the cloud forms, and all other of nature's wonders, photography has given the naturalist inestimable aid in his investigations.

Until the practical application of photography to the microscope, the student was compelled to draw or paint, at great expenditure of time and effort, all that he saw through the eyepiece. It is needless to say that work of this kind was very unsatisfactory; but photographic reproductions of wonderful accuracy are now possible, which may be still further enlarged in the projecting lantern. Thus the specialist demonstrates to his class in the lecture room or laboratory the progress of disease in the minutest structure of fiber, bone, or tissue; the colonization of bacteria in a drop of blood, the wonderful nerve centers of the human system; all these and many other things, photography makes clear under the hand of pathologists, bacteriologists, and the medical profession everywhere With the introduction of the Lumière autochrome color plate during the past year, the various professions are now able to reproduce at one operation th above-named tissues in their true natural colors as they appear to the eye, an improvement of incalculable benefit to all students of medicine, natural history, and art.

In the collection of legal evidence, both with and without the microscope, it is in constant and everincreasing use before the courts. Unmistakable evidence of forgery and erasure not discernible to the naked eye have been shown to jurors through the agency of photo-microscopy; sometimes by faint traces of an underlying portion of a signature not completely obliterated, and often by the condition of the surface fiber of the paper upon which the erasure had been made. By means of direct photographic enlargements, made. By means of direct photographic enlargements,
doubtful signatures have been compared with authentic ones with results that have carried convincing (and convicting) weight. An interesting case in point is that of a noted will bearing four signatures alleged to have been written by the same person, but which upon enlargement were shown to be so exactly similar in every particular as to prove that all four had been in every particular as to prove that all four had been of criminals, the establishment of disputed boundaries, in accidents, railroad wrecks, and fires, photography is indispensable. It is but just to add that the rea value of much photographic evidence depends upon a knowledge of the conditions under which the negatives were made; and urless such knowledge is available, there is danger to the layman in accepting literally the apparent similarities of two or more photographs from different negatives.

Important as it is in these many and varied fields, photography is performing even more wonderful service to science in conjunction with the great telescopes of the astronomical observatories. As in the case of the microscope, the photographic dry plate records with exquisite detail and precision everything the observer sees, and even more than everything; for by reason of their long exposures, astronomical for by reason of their long exposures, astronomical remote as to be invisible to the human eye, though aided by the most powerful telescopes. Almost every prominent observatory in the world has been engaged for the past twenty-five years in the preparation of a photographic chart of the heavens, which when finished will contain records of more than thirty mil lions of stars, varying in size from the fourteenth to the first magnitude.

Investigations into the higher science of astrophysics are revealing through the spectroscope the composition of the heavenly bodies, the presence or absence of different elements in their construction, and many other abstruse problems which photography alone can demonstrate.
The power of photography to picture the minutest details of an atom, itself invisible, or vividly to portray the grandest scenery of the universe, is no less wonderful than its new-found ability to show by means of the mysterious X-rays of the electric cathode the structure of the human body; its bones and cartilages; the organs and many of the processes of life, abnormal growths and diseased tissues, and to locate foreign substances within it. In the twelve or thirteen years since its discovery, X-ray photog. raphy has been of untold value in lessening suffering and death. It is being rapidly developed and perfected, and is now an indispensable adjunct to the equipment of the consulting room and hospital.

In the demonstration of scientific theories based on natural phenomena, photography is an impartial recorder of facts and conditions. A number of years ago, for instance, a noted French scientist advanced the theory that an object rapidly driven through the air would build up before it a cushion of compressed air and leave behind it a wake in just the same manner as does a boat propelled through the water. A bullet fired into a smoke-filled room was made to discharge an electric spark and release a shutter, photographing itself in flight. The resulting photographs clearly demonstrated his theory. The vibra. tions of a tuming fork in response to the notes tions a tum in response to the notes of a been photographed to measure the varying length of

been photograph
sound waves.

Another of its recent important applications is to be found in the work of the topographer, by whom it is now almost universally employed. A topographical chart of the Yukon River district was recently plotted by the U. S. Coast and Geodetic Survey from a series of seventy-six photographic negatives. These negatives, made with lenses of known focal lengths and from certain carefully selected bases, furnished all the data from which, by elaborate mathematical calculations, every desired measurement of distance and altitude was obtained.

In the conduct of military and naval operations, the possibilities of photography have been long recognized, and a great deal of experimental work has been done to develop and perfect methods of photographing from balloons, captive and free, and from kites. Work of this nature is extremely difficult, but enough has been accomplished to demonstrate its value.

The use of photography in commercial life is familiar to all. The builder and contractor make daily photographic records of progress on the construction of skyscraper, subway, and battleship. The artist, architect, and sculptor keep in touch with all the examples of their craftsmanship by its means. The merchant shows his wares, and the manufacturer the products of his factory. An ingenious foreigner has lately invented a photographic method by which the weaving of every ind of fabric, from delicate silks and lace to rugs, carpets, and tapestries, may be greatly simplified and the cost materially reduced.

In its power to portray the human likeness, photography has been of inestimable value to mankind. Until its introduction portraits were beyond the reach of all but the wealthy; to-day there is little excuse for any family to be without pictures of its loved ones. If in these achevements alone were to be found all that photography has accomplished, it might well be credited a tremendous force in world progress; but with them all and the sum of them there is still a single field in which it has done more than in all the others combined-its application to the printing press. Early in its development, photographic methods were employed in lithographic printing, and later in the production of relief plates chemically etched and adapted to the use of ordinary presses; but for years all these processes were restricted to the reproduction of black and white in lines or dots. In other words, every illustration had first to be redrawn and translated into lines, entirely destroying the photographic effect.

It was not until 1855 that a method of printing was found by which the photographic effect of tone and half-tone could be retained without redrawing. This method was costly, involving the use of specially 
constructed presses and gelatine plates. From it have developed other photo-gelatine processes and the in taglio process of photogravure Beautiful as are th results of these processes, their cost and slowness of production render them impossible for general use.

About thirty years ago a method was found of mechanically breaking up the photograph into dots which could be chemically etched upon a printing plate.
This was the beginning of the half-tone process of photo-engraving now so universally employed. No better illustration of its accuracy in reproducing the effect of the photographic original is needed than may be found within the pages of the Supplement.

Only when one considers the vividness and enduring strength of an impression made upon the mind through pictorial demonstration, can one appreciate the value of photographs in popular education; and hen it is remembered that thousands of printing resses in every quarter of the civilized world ar pouring out, with photographic accuracy, steady streams of illustrations, covering every field of inves tigation, and at a cost so low as to make them every where available, its power as an impelling agent in world progress becomes apparent.

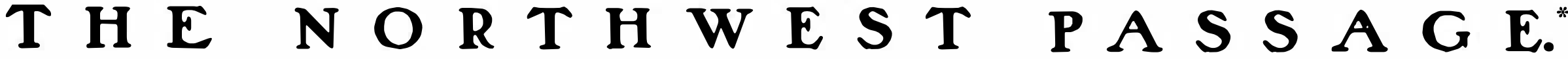

\section{AMUNDSEN'S GREAT ACHIEVEMENT.}

STRICTLY speaking, the northwest passage was ac complished in 1847, when Franklin and his men, re treating from their abandoned ships to the northwest of King William Land, passed through Simpson Strait to the mouth of the Great Fish River, and so crossed the tracks of Dease and Simpson, who in 1839 had reached Castor and Pollux Bay from the west. The existence of channels at least continuous, and possibly navigable, from east to west was thus proved. Later, 185, " she had reached from the Pacific, retreated to the ships of Belcher's squadron, then wintering on the southeast of Melville Island, and ultimately reache home. This was the first party to complete the traverse of the American Arctic regions from ocean to ocean. Technically, McClure did the northwest pass age, but he proved at the same time that his routs was quite impracticable. The "Enterprise," under Collinson, the "Investigator's" companion ship, did more toward the discovery of the passage by reaching Cambridge Bay from the west. Consequently, the only part untraversed by a ship was from the north of King William Lard to the south of Victoria Land. A link of only some 200 miles (by the most direct channels) was all that remained to be forged whe Amundsen planned and equipped his expedition in the "Gjöa." But these facts cannot detract from the interest of the two volumes before us; the length of the "Gjöa's" voyage, no less than its historical impor tance, justifies the many pages.

There is no doubt that Amundsen's expedition will live in the annals of polar exploration in virtue o the accomplishment of the northwest passage; but that was only its secondary aim. "Our first and foremost task was to obtain exact data as to the Magnetic Pole," says Amundsen and repeats it several times. It had long been his ambition to nivigate the northwest passage, but with a praiseworthy self-denial he compelled himself to keep the fulfillment of this feat compelled himself to keep the fulfillment of this feat
of navigation subordinate to his scientific researches in magnetism. And yet in perusing the pages of the book one feels that the adventurous spirit of the Norseman was kept in check with difficulty; the desire to accomplish the passage was uppermost in his mind, and when once the greater part of the magnetic work was behind him his hearty enthusiasm seems to have been redoubled. have been redoubled. However, in spite of this, Amundsen retained the "Gjoa" for nineteen months in wand so that he could fulfill his programme of mag netic work, and this notwithstanding the fact that he saw open water ahead, and in all probability no obstacle in his road to the Pacific. That was an exhib tion of devotion to scientific work in face of the greater fascination of an adventurous voyage which is most commendable and by no means common in polar exploration.

The "Gjöa"-a vessel of cnly forty-seven tons-left Christiania in 1903, and traversing Lancaster Sound and Barrow Strait reached Peel Sound. Amundsen was fortunate in finding Peel Sound open, as Franklin did in 1846 (but not so M'Clintock in 1858), and encountering no difficulties he sailed down Franklin Strait and entered Ross Strait to the east of King William Land. Here he was in virgin waters, for although M'Clintock had sledged down this strait in 1858, the "Erebus" and the "Terror" had passed to the west of King William Land in ignorance that there was a passage to the east. It was Rae who discovered the insularity of that land, and he held the opinion -afterward shared by M'Clintock-that the only navigable passage was along its eastern and southern Strait, narrow and encumbered with islands as it is, must always prove as insuperable an obstacle as it did to the "Erebus" and the "Terror." Amundsen had reason to congratulate himself on following Rae's advice in this matter. Passing along Rae Strait the "Gjöa" went into winter quarters in September in a snug little harbor on the southeast of King William
Land, since christened Gjøa Haven. The situation admirably suited the requirements of the work, which, the author explains, demanded such a distance from the magnetic pole that the inclination would be about 89 deg. From this base frequent excursions were made in all directions, Amundsen himself sledging on one occasion northward as far as the locality of the magnetic pole in Boothia felix. By his observations he proved the truth of the theory that the mag netic pole has not a stationary position, but, on the contrary

During April, May, and June, 1905, Lieut. Hansen, ccompanied by Ristvedt, made a sledge journey to Victoria Land, and succeeded in charting, as far a 72 deg. N., the western shores of M'Clintock Channel, the supposed breadth of which he found had been Haakon VII. Coast. In addition, the "land seen by Rae" in Victoria Strait, which proved to be a group of many islands, was charted, though the work seems to many islands, was charted, though the work seems
to have been done somewhat roughiy. These surveys included all the topographical work of the expedition; nowhere else did the explorers touch quite new land In August, 1905, the westward journey was resumed and after some tortuous navigation through an islan group in the north of Queen Maud Sea, Campridge "Enterprise." Thence onward until King Point made navigation was relatively simple, but at that point the "Gjöa" was stopped by ice, and compelled point the "Gjo" was stopped by ice, and compelled
to pass a third winter. In the summer following she reached Nome City, and ultimately San Francisco, where she now lies, waiting, we understand, for the completion of the Panama Canal to return to Europe Amundsen thus accomplished the northwest passage, and, moreover, found a route that would probably be practicable for a small ship in any year if only The greatest difficulty in the whole passage lies in entering Franklin Strait, for Peel Sound and Bellot Strait, both of which Amundsen found open, may just as likely be blocked with pack-ice, as M'Clintock found them. Neither Ross nor Rae Straits appear to give much trouble, though in thick weather navigation in the vicinity of the magnetic pole must be, as maux insist it somewhat hazardous. The Esquimaux insist that Simpson Strait breaks up every year, and while Queen Maud Sea probably is seldom
navigable, the passage through Palander or Markham Straits, though intricate, is possible; three fathoms was the shoalest water found

Except for the work in Victoria Strait and M'Clin tock Channel, the voyage can scarcely be called one of exploration. The greater part of the route was relanever absolutely out of touch with the civilized world. Even at King William Land they got a mail by Esquimaux from Cape Fullerton, Hudson Bay, while at King Point they were in the company of whalers, missionaries, and policemen. During that winter Amundsen made a journey to Eagle City to get into cable communication with Europe. The main scien tific work, magnetism, was successfully carried out and a good series of meteorological observations were taken, at least in winter quarters. Lindström, the cook, was an enthusiastic collector of plants and animals, but, though one of the party was a geologist, we do not gather that geological observations and collections were made, except a few fossils at Boothia Felix and King William Land. That is a pity in view of the many opportunities that must have occurred dur ing a voyage practically always within touch of land. Nor do we gather that any soundings were taken other than those essential for the navigation of the "Gjea"; certainly none are indicated on the outline maps which accompany the volume. However, with regard to the Esquimaux encountered, very full information is given. The first two winters were passed in the company of the little-known Nechilli tribe. They appear to be one of the few tribes of Esquimaux who fortunately have had little or no contact with white men, though it was from members of Amundsen tells his story in a lucid, interesting style, and, though the book would not lose by condensation in places, it is singularly free from the trivialities with which such volumes are often loaded. But an appendix of scientific results would have given more permanent value to these volumes.

One rather serious error on page 59 should be men tioned. The author speaks of passing through Bellot Strait when he evidently only passed by the end of it. A very full and accurate index is provided.Nature.

\section{ACTION OF RADIUM EMANATION ON} COPPER SALTS.

By Mme. Curie and Mlle. Gleditsch.

Messrs. Ramsay and Cameron announced a year ago that they observed the production of alkaline met als and lithium in solutions of copper salts which were submitted to the action of radium emanation, and they concluded that they had an example of transformation of the elements. The copper was changed to elements of the same group having a less atomic weight, such as potassium. sodium, and lithium. In their experiments a copper solution placed in a bulb was left in contact with a strong radium emanation. The copper was separated, and the residue examined. It consisted especially of a sodium salt, with a small amount of potassium and calcium. Lithium was detected by thr spectroscope. In a check solution, the residue was much less, and lithium was not found. Malame Curie and Mlle. Gleditsch recently repeated the exducts which are quite free from lithium, and this latter is found in distilled water and in nearly all the reagents. If a substance is left in a glass vessel for a time, it is found to contain traces of lithium. It was therefore necessary to replace the glass by another material. Quartz is objectionable, as the commercial quartz vessels also contain lithium. Platinum was finally used in the form of a cylinder 3 inches long and 0.6 inch diameter, placed horizontally, and having at the end a small platinum tube for introducing the solution. The reagents were purified so as to be free from lithium. The pure copper salts of commerce, as Mr. Ramsay remarked, are found to contain lithium. The copper salts were purified by a special process, so that finally they were quite free from the metal. The radium emanation was furnished by a solution containing 0.19 gramme of radium (or 0.25 gramme of radium chloride). It was introduced into the apparatus after having been first condensed in a worm-tube placed in liquid air. After the copper salt (sulphate of copper) had been acted upon for some time by the emanation, the solution was withdrawn and placed in a platinum crucible. The copper was deposited electrolytically by means of a platinum electrode plate, and the residue of copper was precipitated by hydrogen sulphide. The liquid was then evaporated and the very slight residue weighed. A like amount (7 cubic centimeters) of pure copper sulphate solution which had not received the emanation was likewise treated and the two residues were examined by the spectroscope. The weights of the residue of the solution heated with radium were 0.0004 and 0.0005 gramme, and for the untreated solution, 0.0003 and 0.0002 gramme. The amount of copper used was about the same as in Mr. Ramsay's work, but the residue was much smaller. Spectroscopic tests showed that the residue contained mainly sodium and a small amount of potassium, but lithium was not found. The residue is in any case much smaller than that obtained by Mr. Ramsay, and this is probably due to the suppression of the glass. A number of check experiments were made, and the result is that the present experimenters were not able to confirm the results obtained by Messrs. Ramsay trace of sodium or lithium is formed in the experiments, they of these elements cannot be said to be established.

The State Department makes the announcement officially that the world's fair which was to have been held at Tokio in 1912 has been postponed by the Japanese until the year 1917. 